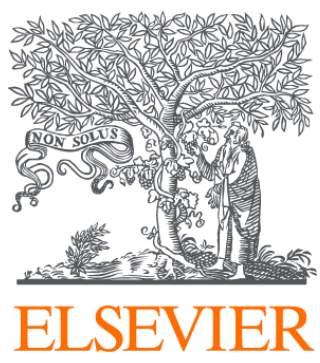

Since January 2020 Elsevier has created a COVID-19 resource centre with free information in English and Mandarin on the novel coronavirus COVID-

19. The COVID-19 resource centre is hosted on Elsevier Connect, the company's public news and information website.

Elsevier hereby grants permission to make all its COVID-19-related research that is available on the COVID-19 resource centre - including this research content - immediately available in PubMed Central and other publicly funded repositories, such as the WHO COVID database with rights for unrestricted research re-use and analyses in any form or by any means with acknowledgement of the original source. These permissions are granted for free by Elsevier for as long as the COVID-19 resource centre remains active. 
epidemiological grounds that they repeated themselves in tandem over many years in many countries-but what little doubt ${ }^{2}$ there may have been now seems removed. All sera and CSFs were also tested for NT to three types of poliovirus and the EH-24 variant strain of Coxsackie A24 virus, which causes clinically similar conjunctivitis. ${ }^{3}$ However, our results clearly indicated that these viruses had nothing to do with the 1981 epidemic of AHC or its neurological complications in Bombay (data not shown).

These are very preliminary observations, as we have yet to analyse the bulk of the material available.

\author{
Department of Bacteriology, \\ Saitama Medical School, \\ And Central Virus Diagnostic Laboratory, \\ National Institute of Health, \\ Tokyo, Japan

\section{Department of Neurology} \\ Sir J.J. Group of Hospitals \\ and Jaslok Hospital and Research Centre, \\ Bombay, India
}

K. MIYAMura

T. OGINO

N. H. WADIA

P. N. WADIA

S. M. KATRAK

V. P. MISRA

\section{ENTERIC ADENOVIRUSES AND ROTAVIRUSES IN INFANTILE GASTROENTERITIS IN DEVELOPING COUNTRIES}

SIR,-The letter by Dr Dowling and Dr Wynne (Aug. 8, p. 305) is of great interest to us. Their disparate detection rates of adenovirus and rotavirus from stool samples taken in two different rural areas in South Africa is intriguing and warrants further investigation. However, I would hesitate to ascribe an aetiological role to these adenoviruses merely on the basis of electron microscopy of stools of patients with diarrhoea and vomiting. Further work is needed to differentiate these viruses from respiratory adenoviruses and commensal enteric adenoviruses.

We are surprised that Dowling and Wynne "are aware of no other studies on the incidence of adenovirus-associated gastroenteritis in southern Africa", apart from our 1975 report. ${ }^{4}$ Since that time we have published papers on the aetiology of acute infantile gastroenteritis in our Black urban communities in the Pretoria ${ }^{5}$ and the Johannesburg ${ }^{6,7}$ areas. Stools were examined by negative-staining electron microscopy and we were unable to detect adenoviruses in any of these specimens. The rates of rotavirus detection were low, varying from $6 \%{ }^{2}$ to $19 \%,{ }^{7}$ and this was thought at first to be due to patients reporting for medical care late in the course of their illness when the excretion of virus particles dropped below the detection limit of the electron microscope. ${ }^{5}$ In a recent study (unpublished) the low rotavirus detection rate in the Black population ( $7 \%, 3$ out of 41) was confirmed by enzyme-linked immunosorbent assay as well as by electron microscopy; in contrast, the figure for the White population was $56 \%$ (14 out of 25). Adenovirus was again conspicuously absent. The reasons for this low frequency of rotavirus in the Black population, which does not appear to be related to the high incidence of lactase deficiency in this population, ${ }^{8}$ are being investigated.

Whether our failure to detect adenovirus is due to technical factors or represents a real difference in incidence of infection between urban and rural populations needs further work. We have previously noted striking differences in detection rates of coronavirus-like particles between rural and urban Black populations; these agents were seen in 35 of 103 stool samples taken

2. Editorial. Acute haemorrhagic conjunctivitis. Lancet 1973; 1: 13.

3. Mirkovic RR, Schmidt NJ, Yin-Murphy M, et al. Enterovirus etiology of the 1970 Singapore epidemic of acute conjunctivitis. Intervtrology 1974; 4: 119-27.

4. Schoub BD, Koornhof HJ, Lecatsas G, Prozesky OW, Freiman I, Hartman E, Kassel $H$. Viruses in summer gastroenteritis in black infants. Lancet 1975, i: 1093

5 Schoub BD, Greeff AS, Lecatsas G, Prozesky OW, Hay IT, Prınsioo JG, Ballard RC. A Microbiological Investigation of acute summer gastroenteritis in Black South African infants. 7 Hyg Camb 1977; 78: $377-85$

6. Freıman I, Hartman E, Kassel, H, Robins-Browne RM, Schoub BD, Koornhof HJ, Lecatsas G, Prozesky OW. A microbiological study of gastroenterıtıs in Black infants. S Afr Med F 1977; 52: 261-65.

7. Robins-Browne RM, Stıll CS, Miliotıs MD, Rıchardson NJ, Koornhof HI, Freıman I Schoub BD, Hartman E, Lecatsas G. Summer diarrhoea in African infants and children. Arch Dis Child 1980; 12: $923-28$

8. Schoub BD, Jenkıns T, Robins-Browne RM. Rotavirus Infection in a high-incidence lactase-deficiency population. Lancet 1978; i: 328. from healthy rural Black schoolchildren in the Western Transvaal (Schoub BD, Spence IM, unpublished) but are rarely seen in stools from Black or White urban subjects. The pathological significance of these differences is unclear. Perhaps there are significant differences in viral gut flora between populations with differing diets and life-styles, as with the enteric bacterial flora. ${ }^{9}$

Department of Virology,

University of Witwatersrand,

National Institute for Virology,

Sandringham 2131, South Africa

BARRY D. SCHOUB

\section{ALCOHOL AND PORPHYRIA}

SIR,-We read Professor With's letter (Sept. 19, p. 639) with interest and not a little dismay. He states that in his wide experience of acute porphyria he has never encountered an attack induced by alcohol and consequently does not advise his patients to abstain from drinking. His experience is completely contrary to our own. We strongly advise all of our patients with acute porphyria that alcohol may precipitate a porphyric attack.

In the past three years alone our unit in Glasgow has supervised the inpatient management of 79 attacks of acute intermittent porphyria in twenty-four patients. 4 of these attacks proved fatal. 11 $(13 \%)$ of the attacks were precipitated by alcohol ingestion, making alcohol the third commonest precipitating factor, preceded only by drugs and the premenstrual hormonal fluctuations. Our experience in the management of porphyria over three decades is similar. On several occasions, we have been surprised by the small quantities of alcohol which have triggered attacks in some of our patients with frequently relapsing porphyria. Two patients who have each had, over the past three years, an average of 7 attacks per year, have independently discovered that drinking only one glass of vodka or two glasses of sherry is sufficient to precipitate an attack. On the basis of their personal experience of the effects of alcohol on their porphyria, both have become teetotal.

The porphyrinogenicity of a substance is dependent on its ability to induce the initial and rate-controlling enzyme of haem biosynthesis, delta-aminolaevulinic acid (ALA) synthase. ${ }^{1}$ Ethanol is a well known porphyrinogen and induces hepatic ALA synthase activity in laboratory animals. ${ }^{2}$ We have demonstrated in healthy non-porphyric subjects that the ingestion of $200 \mathrm{ml}$ vodka $(1 \cdot 316$ mol ethanol), raises the activity of leucocyte ALA synthase by a mean of $110 \%{ }^{3}$ and similar distrubances of haem biosynthesis are observed in alcoholics. ${ }^{4}$

One should also remember that the primary aetiological agent in the development of cutaneous hepatic porphyria is ethanol, as a consequence of its effects upon haem synthesis. It is for these reasons that alcohol figures so largely on lists of drugs contraindicated in the porphyrias. ${ }^{5}$

With recommends more liberal use of drugs as well as of alcohol in porphyria patients. We agree that it is difficult to be certain of the safety or otherwise of certain drugs in acute porphyria. The response also varies from patient to patient. However, we must strongly advocate caution and avoidance of potential porphyrinogens when prescribing for and advising porphyria patients, as detailed in the recent international review. ${ }^{5}$ There is still no dependable form of therapy for the acute attack ${ }^{6}$ so prevention of such attacks is of paramount importance.

$\begin{array}{ll}\text { Department of Medicine, } & \text { A. GoLDBERG } \\ \text { Gardiner Institute, } & \text { K. E. L. MCCOLI } \\ \text { Western Infirmary, } & \text { M. R. MOORE } \\ \text { Glasgow G11 6NT } & \end{array}$

9 Tomkıns AM, Bradley AK, Oswald S, Drasar BS. Diet and the faecal microflora of infants, chıldren and adults in rural Nigerıa and urban U.K. J Hyg Camb 1981, 86: $285-94$

1. Smith AG, de Matress F Drugs and the hepatic porphyrias. In Goldberg A, Moore $M R$, eds. Clinics in haematology: The porphyrias. London: Saunders 1980 $339-425$.

2 Shanley BC, Zail SS, Jouberr SM Effect of ethanol on liver delta-aminoaevulınate synthase in rats Lancet 1968,1 70-71.

3. McColl KEL, Thompson GG, Moore MR Goldberg A Acute ethanol ingestion and haem biosynthesis in healthy subjects. Eur f Cln Invest 1980, 10: 107-12

4 McColl KEL, Moore MR, Thompson GG, Goldberg A Abnormal haem biosynthesis in chronic alcoholics. Eur $\mathcal{F}$ Clin Invest (1n press).

5. Moore MR. International review of drugs in acute porphyria Int f Blochem 1980, 12: 1089-097.

6. McColl KEL, Moore MR, Thompson GG, Goldberg A Haematin therapy for acute hepatic porphyria. Quart f Med 1981, 198: 161-74. 